\title{
Journal of General and Family Medicine Check Sheet
}

When you submit an article to Journal of General and Family Medicine, please check the box and send this document to us by email in PDF format.

The file size limitation of an article is $10 \mathrm{MB}$ or under.

Title Page Publication category: Manuscript title: Authors name: Name and address of Institution: Preferred email address: List of Keywords (maximum 5):

Category: Check the box; $\square$ original articles $\square$ editorials $\square_{\text {special articles }} \square_{\text {review articles }}$ $\square$ preliminary reports $\square$ case reports $\square$ images in clinical medicine $\square_{\text {letters }}$

Text Specifications

Article Outline:

Text: Word format.

Headings: Introduction, methods, results, discussion, conclusion.

$\square$ List page number, line number, and total word count.

Abstract: Please provide a structured abstract.

$\square$ Each section, whether title page, abstract, main text, references, or figures and tables, need to be numbered appropriately.

$\square$ Please write the article in double space.

References should be formatted in the following style.

\section{Articles:}

Braddock $\mathrm{CH}$, Fihn SD, Levinson W, et al: How doctors and patients discuss routine clinical decisions informed decision making in the outpatient setting. J Gen Intern Med. 1997;12:339-345.

\section{Books:}

Fleiss JL: Statistical methods for rates and proportions. New York: John Wiley and Sons, 1981, 165-168.

\section{Websites:}

Health Care Financing Administration. 1996 statistics at a glance. Available at: http:// www.hcfa.gov/stats/stathili.com. Accessed December 2, 2014.

$\square$ Please ensure the total word number of the main text does not exceed more than following limit.

(1) original articles, 3500 words, (2) editorials, 1200 words, (3) review articles, 4000 words, (4) preliminary reports, 1000 words, (5) case reports, 1000 words, (6) images in clinical medicine, 500 words, (7) letters, 500 words.

Tables are required to be in MS Office format. Version 97-2003 or later. All tables should be included within a single file.

All figures are required to be in MS Office Powerpoint format. Version 97-2003 or later.

$\square$ Conclusion: Title page, main text (including references and legends), table and figures must be sent to us in four separate files.

$\square$ Please ensure that no conflict of interest is present within your article and our organization. Please send COI Self-Report Form to us by email in PDF format.

All authors are required to officially authorize (in writing) the publication of their article. Please send Copyright Transfer Agreement to us by email in PDF format.

$\square$ After completing this check sheet please send it to us by email in PDF format. 